\title{
A Review on DNA Repair Inhibition by PARP Inhibitors in Cancer Therapy
}

\author{
Ashish P. Shah ${ }^{1}$, Chhagan N. Patel ${ }^{2}$, Dipen K. Sureja ${ }^{1}$, Kirtan P. Sanghavi ${ }^{1}$ \\ ${ }^{1}$ Department of Pharmacy, Sumandeep Vidyapeeth University, Vadodara, India \\ ${ }^{2}$ Department of Pharmaceutical Chemistry, Shree Sarvajanik Pharmacy College, Mehsana, India
}

\section{Correspondence:}

Ashish P. Shah, Department of Pharmacy, Sumandeep Vidyapeeth University, At po: piparia; Taluka: waghodiya;

Vadodara, 391760, India

Email:shah_ashishpharmacy@ yahoo.co.in

Tel: +91 9909984159

Received: 25 May 2017

Accepted: 24 June 2017

Published Online: 17 July 2017

Published: 30 March 2018

Key words: DNA damage repair, Poly(ADP-ribose) polymerases, PARP inhibitors, cancer

Citation: Shah AP, Patel CN , Sureja DK, Sanghavi KP. A review on DNA repair inhibition by PARP inhibitors in cancer therapy. Folia Med (Plovdiv) 2018;60(1):39-47.

doi: 10.1515/folmed-2017-0067
The DNA repair process protects the cells from DNA damaging agent by multiple pathways. Majority of the cancer therapy cause DNA damage which leads to apoptosis. The cell has natural ability to repair this damage which ultimately leads to development of resistance of drugs. The key enzymes involved in DNA repair process are poly(ADP-ribose) (PAR) and poly(ADP-ribose) polymerases (PARP). Tumor cells repair their defective gene via defective homologues recombination (HR) in the presence of enzyme PARP. PARP inhibitors inhibit the enzyme poly(ADPribose) polymerases (PARPs) which lead to apoptosis of cancer cells. Current clinical data shows the role of PARP inhibitors is not restricted to BRCA mutations but also effective in HR dysfunctions related tumors. Therefore, investigation in this area could be very helpful for future therapy of cancer. This review gives detail information on the role of PARP in DNA damage repair, the role of PARP inhibitors and chemistry of currently available PARP inhibitors.

\section{INTRODUCTION}

Cancer is one of the major human health problems worldwide. The discovery of new target based therapy has opened a new window in the treatment of cancer. One major problem in current cancer chemotherapy is resistance development and severe toxic effects. Resistance may occur through several different cell mechanisms. Therefore, the challenge is to identify new less toxic drugs and to improve the existing cancer therapy. There is active research going on to identify targets whose expression or activation increases cancer growth. The cell DNA repair mechanism may provide important information on the above stated problem. ${ }^{1}$ PARP is the enzyme which is involved in the DNA damage repair process. Inhibition of PARP may induce apoptosis (Fig. 1). PARP enzymes are important for many cellular functions $^{2}$ which includes inflammatory gene ${ }^{3}$ in smooth muscles to response tumor necrosis factor (TNF). ${ }^{4}$
DNA damage

from endogenous and exogenous source

DNA damage to cells with Proliferative capacity

Errors of Replication or repair

Mutation conferring selective advantage for clonal expansion \& premalignant field defect

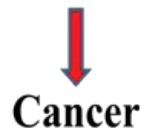

Figure 1. Link between DNA damage repair and cancer. 
PARP inhibitors inhibit the enzyme poly(ADPribose) polymerases (PARP). The most important role of PARP inhibitors is in treatment of cancer. ${ }^{1}$ Some types of cancers (ovarian and breast) depend on PARP inhibition..$^{5-7}$ PARP inhibitors can also be useful in other diseases like stroke, myocardial infarction and long term neurodegenerative diseases. ${ }^{8}$

This review gives detailed information of the link between DNA damage repair and cancer, the role of PARP in DNA damage repair, the medicinal importance of PARP inhibitors and its role in the treatment of different cancers.

\section{PARP STRUCTURE}

PARP structure is made up of four different units. 1. DNA binding domain: it contains two zinc finger motifs. In case of DNA damage, this domain binds with DNA and induces conformational shift.
2. Auto-modification domain: it releases protein from DNA.

3. Caspase cleaved domain: this cleavage inhibition induces cell death program.

4. Catalytic domain.

Fig. 2 shows the catalytic activity of PARP. The cleavage of NAD + moiety liberates ADP ribose monomer (blue) and nicotinamide moiety (red) in presence of PARP. This chain supplies DNA repair proteins. ${ }^{9,10}$

\section{ROLE OF PARP IN DNA REPAIR}

PARP is located in the cell nucleus. The main function of PARP is to detect and signal single strand DNA breaks (SSB) and give message to the machinery section which is involved in the repair of SSB. Several factors like metabolic, chemical or radiation undergo SSB which activates the PARP.

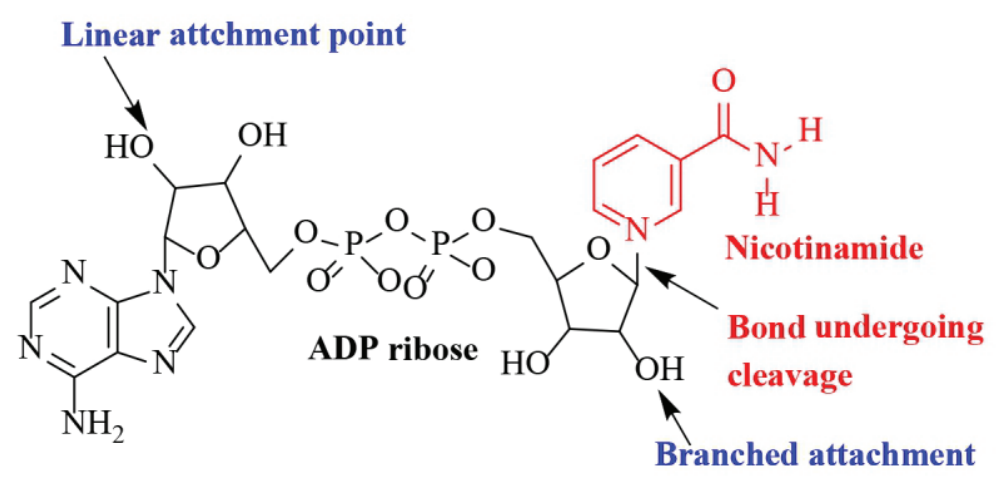

Figure 2. Catalytic activity of PARP.

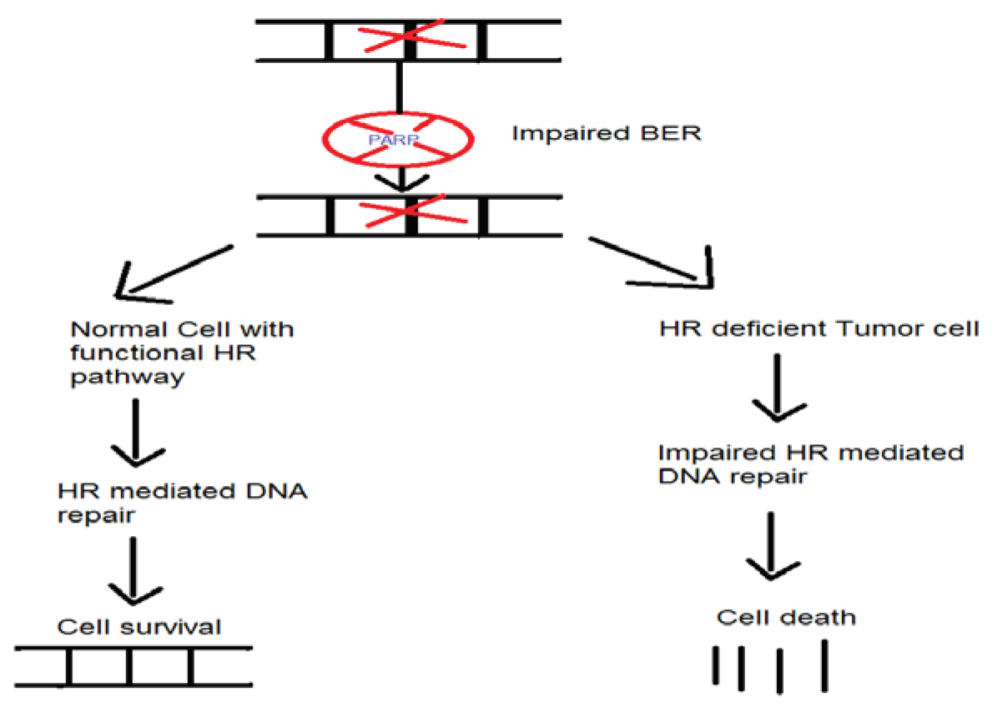

Figure 3. Mechanisms of PARP inhibitors to produce cell death without affecting normal cells. 
After detection of SSB, PARP binds with DNA, does structural modification and starts the synthesis of poly(ADP-ribose) chain (PAR) to provide signal to DNA repairing enzymes like DNA ligase III (LigIII), DNA polymerase beta (pol $\beta$ ), and scaffolding proteins such as X-ray cross-complementing gene 1 (XRCC1). Once repair is done PAR chains is degraded by the enzyme glycohydrolase. ${ }^{11} \mathrm{NAD}^{+}$ is required to generate ADP-ribose monomers. It has been found that overactivation of PARP leads to disturbance in glycolysis due to the reduction of cellular $\mathrm{NAD}^{+}$and ATP. PARP is inhibited by DNA caspase-III cleavage which produces cell death.

\section{DNA REPAIR MECHANISMS AND ROLE OF PARP INHIBITION}

DNA is unstable, alterations of DNA mechanism occur through different factors like environmental or by-products of normal cellular metabolism or disruption of chemical bond in DNA. ${ }^{12}$ This activity causes single strand breaks (SSBs), double strand breaks (DSBs) and intra- or inter-strand cross-links.

This DNA damage is repaired by four different DNA repair mechanisms: base-excision repair (BER), nucleotide-excision repair (NER), mismatch repair (MMR), homologous recombination (HR) and non-homologous end-joining (NHEJ). SSBs are repaired by BER, NER, and MMR while DSBs are repaired by HR and NHEJ. Some DNA can be repaired directly.

\section{NORMAL DNA REPAIR MECHANISMS AND ROLE OF PARP IN SSBS AND DSBS REPAIR}

Modification of single DNA strand including SSBs is the most common deviation. Repairing by BER, NER, and MMR provides remaining uninjured strand as complementary which act as a template. ${ }^{12}$ Approximately 10,000 spontaneous SSBs occur every day in each cell. ${ }^{13}$ The BER pathway generates PARP enzyme which is involved in repair mechanism. ${ }^{12}$ For the first time PARP was described in 1963 which involves 17 members and amongst them PARP-1 is the most important. ${ }^{14}$ The PARP function is to bind to SSBs in BER pathway. ${ }^{15-17}$ PARP can also get involved in the NER pathway. ${ }^{18}$ Thus, PARP plays an important role in DNA damage repair and stabilization.

\section{DSBS REPAIR}

SSBs convert to DSBs via replication. DSBs damage can be induced by X-rays, chemical or other fac- tors and repaired by HR pathway which is an error free repair. Due to unavailability of complementary DNA strand, it is potentially more problematic than SSBs. If it is repaired by NHEJ, it causes error and leads to change in DNA sequence at break site. ${ }^{12}$

\section{ABNORMAL SSBS AND DSBS REPAIR AND PARP DEFICIENCY}

DNA damage leads to activation of PARP-1 and PARP-2. PARP-1 deficiency doesn't create any problem in non-malignant cells though PARP-1 have an important role in SSBs repair. ${ }^{16,19,20}$ The loss of PARP-1 guides DNA damage repair with different pathways. Unrepaired SSBs convert into DSBs which is repaired by HR in the presence of BRCA1 and BRCA2 is an error free pathway. ${ }^{19,21-23}$ PARP inhibition blocks the conversion of SSBs to DSBs. PARP-1 inhibition blocks the repair of SSBs but the repair of DSBs proceeds further. ${ }^{22,23}$

Deficiency of BRCA functions forces cells to repair DSBs via NHEJ or single strand annealing sub pathway of HR but both mechanisms produce errors. BRCA deficient cell either dies or produces DNA mutations if it survives. Clinically, it has been observed that BRCA deficiency increases the risk of some cancers such as breast cancer and ovarian cancer. ${ }^{24,25}$ It was also reported that the clinical role of PARP inhibitors is not restricted to BRCA deficient cancer but also in tumors occur due to dysfunction of HR pathway with less toxicity. ${ }^{24}$ (Fig. 3)

\section{ONGOING RESEARCH IN PARP INHIBITORS}

The first identified PARP-1 inhibitor was based on a composition of $\mathrm{NAD}^{+}$moiety. They were designed structurally similar to the nicotinamide moiety. 5-methyl nicotinamide derivatives were developed as competitive inhibitor of PARP. Similarly benzamide derivatives were also synthesized but they show weak inhibition. ${ }^{1}$ With the help of X-ray crystallography, the crystal structure of catalytic domain of PARP with inhibitor is established. ${ }^{26}$ After this new PARP inhibitors developed which have more selectivity and potency towards PARP-1. ${ }^{27,28}$ The structure activity relationship of various PARP inhibitors is illustrated in Fig. 4.

Penning et al. ${ }^{29}$ have reported of a novel series of cyclic amine-substituted benzimidazole analogs ${ }^{1}$ and developed SAR. They have found that introduction of amine group at the second position in benzimidazole improves potency. These compounds 


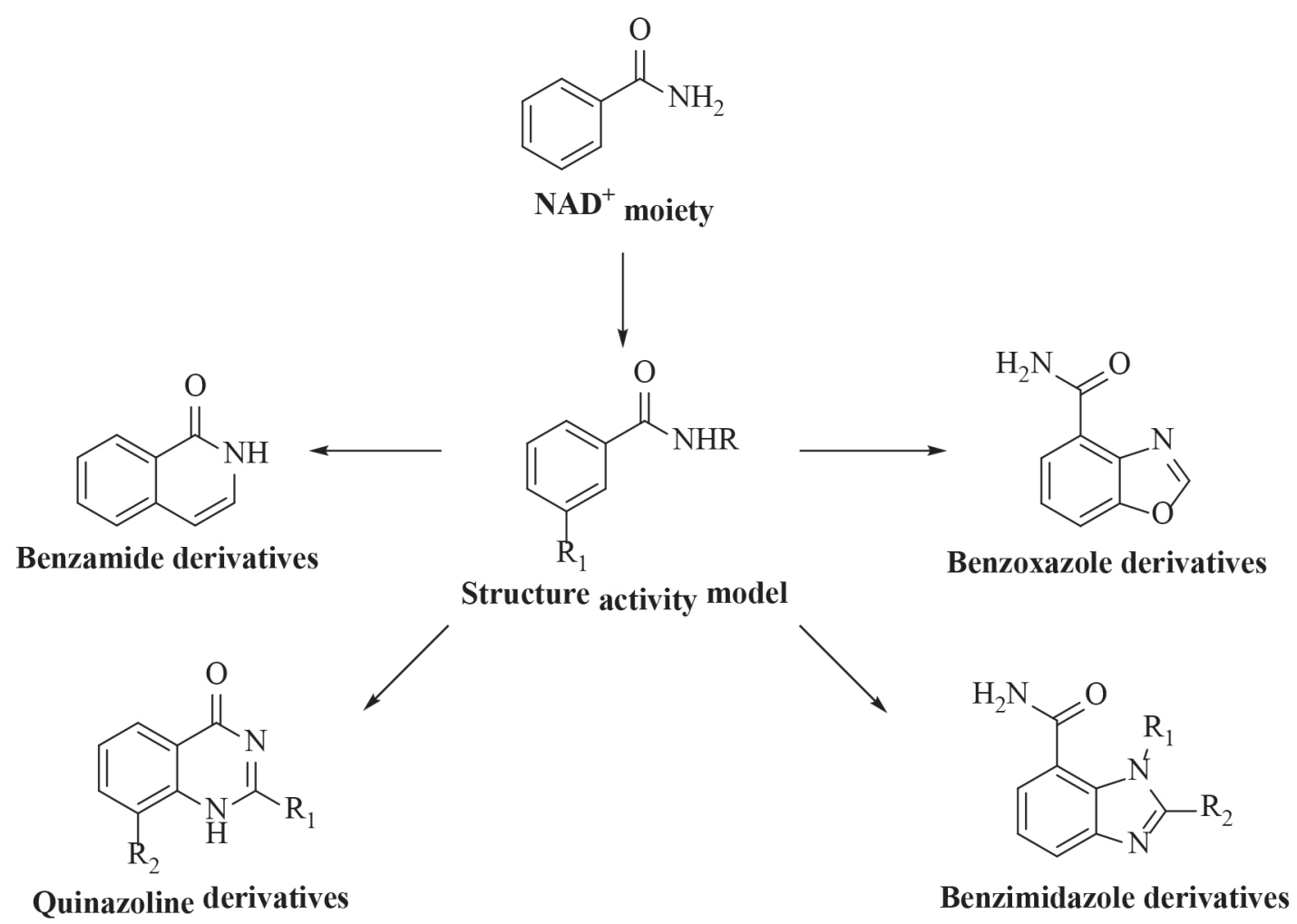

Figure 4. Structure activity model of PARP-1 inhibitors derived from the nicotinamide core structure.<smiles>[R]c1nc2c(C(N)=O)cccc2[nH]1</smiles>

(1)<smiles>[R]N([R])C(C)(C)c1nc2c(C(N)=O)cccc2[nH]1</smiles>

(2)<smiles>NC(=O)c1cc(F)cc2cn(-c3ccc(NC(=O)C4CNC4)c(F)c3)nc12</smiles>

(3)<smiles>CCCN1CCC(c2nc3c(C(N)=O)cncc3[nH]2)CC1</smiles>

(4)<smiles>[R]N1CCC(c2nc3c(C(N)=O)cncc3[nH]2)CC1</smiles>

(5)

Figure 5. Examples of PARP inhibitors reported with good inhibitory activity. 
help to potentiate the efficacy of radiation therapy and several cytotoxic agents like temozolomide (TMZ) and cisplatin.

Zhu et al. ${ }^{30}$ reported novel quaternary methyleneamino substituent at $\mathrm{C}-2$ position of benzimidazole moiety. ${ }^{2}$ They found that introduction of quaternary methylene-amino substituent at C-2 position improves aqueous solubility as well as potency.

A potent series of substituted 2-phenyl-2Hindazole-7-carboxamides were evaluated as PARP inhibitors. After an extensive study of SAR on indazole scaffold and the pendant phenyl ring compound $^{3}$ was identified as potent PARP inhibitor with $\mathrm{IC}_{50}=4 \mathrm{nM}$ (nano molar). ${ }^{31}$

Zhu et al. ${ }^{32}$ reported series of novel cyclic amine-substituted imidazo[4,5-c]pyridine carboxamide analogs as potent PARP-1 inhibitors. They in Fig. 6. Details of some PARP inhibitors in clinical trials and their toxicity profiles are given in Tables 1 and 2 , respectively.

\section{CONCLUSION}

PARP is an emerging target for cancer therapy. PARP inhibitors have shown promising results in some cancer related to BRCA mutations as well as mutations related to HR dysfunctions. Moreover current clinical studies of PARP inhibitors show common adverse effects and toxicity profile is nearly similar to current chemotherapeutic agents. However, clinical efficacy of PARP inhibitors need to be check for long-term therapy before making it a part of clinical practice. New strategies are being<smiles>O=C(c1cc(Cc2n[nH]c(=O)c3ccccc23)ccc1F)N1CCN(C(=O)C2CC2)CC1</smiles><smiles>NC(=O)c1cccc2cn(-c3ccc([C@H]4CCCNC4)cc3)nc12</smiles>

Niraparib

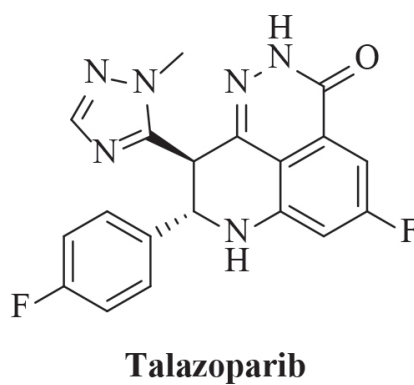

Talazoparib<smiles>C[C@]1(c2nc3c(C(N)=O)cccc3[nH]2)CCCN1</smiles>

Veliparib

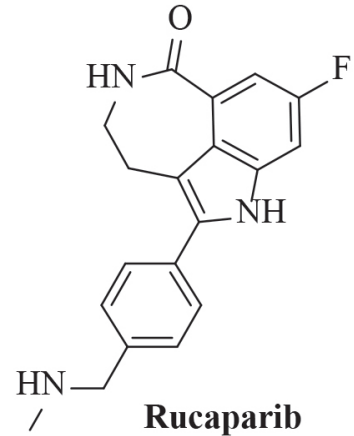<smiles>NCc1ccc2[nH]c3c4c(c5c(c3c2c1)C(=O)NC5=O)CCC4</smiles>

CEP-9722

Figure 6. Structures of PARP inhibitors in clinical trials.

found that combination of compound ${ }^{4}$ with cisplatin is effective at well tolerated doses when administered orally.

Abdullah et al. ${ }^{33}$ reported novel benzimidazole derivatives as PARP-1 and dihydroorotate dehydrogenase (DHODH) inhibitor. Amongst them some derivatives had shown good potencies ${ }^{5}$ (Fig. 5).

\section{CURRENT PARP INHIBITORS IN CLINICAL TRIALS}

The structures of various PARP inhibitors are shown developed to expand application of PARP inhibitors which show more selectivity towards PARP with more potency and lower toxicity.

\section{REFERENCES}

1. Martin NM. DNA repair inhibition and cancer therapy. J Photochem Photobiol B 2001;63(1):162-70.

2. Piskunova TS, Yurova MN, Ovsyannikov AI, et al. Deficiency in poly(ADP-ribose) polymerase-1 (PARP-1) accelerates aging and spontaneous carcinogenesis in mice. Curr Gerontol Geriatr Res 
Table 1. Some PARP inhibitors in clinical trials

\begin{tabular}{|c|c|c|c|}
\hline Drug name & $\begin{array}{l}\text { Pharmaceutical } \\
\text { company }\end{array}$ & $\begin{array}{l}\text { Clinical } \\
\text { phase }\end{array}$ & Current clinical phase \\
\hline Olaparib (AZD2281) 34 & AstraZeneca & 3 & BRCA mutated breast cancer \\
\hline \multirow[t]{2}{*}{ Veliparib $($ ABT-888) 35} & \multirow[t]{2}{*}{ Abbvie } & 3 & $\begin{array}{l}\text { Combination therapy in triple-negative } \\
\text { breast cancer }\end{array}$ \\
\hline & & 2 & BRCA mutated breast cancer \\
\hline $\begin{array}{l}\text { Niraparib (formerly MK- } \\
4827)^{36}\end{array}$ & Tesaro & 3 & BRCA mutated breast cancer \\
\hline Talazoparib (BMN-673) 37 & $\begin{array}{l}\text { BioMarin Pharma- } \\
\text { ceuticals }\end{array}$ & $\begin{array}{l}3 \\
2\end{array}$ & $\begin{array}{l}\text { Germline BRCA mutated breast cancer } \\
\text { advanced and neoadjuvant settings in } \\
\text { BRCA mutated breast cancer and BRCA } \\
\text { intact breast cancer }\end{array}$ \\
\hline $\begin{array}{l}\text { Rucaparib (formerly AG- } \\
\text { 14699) }\end{array}$ & Clovis Oncology & 2 & $\begin{array}{l}\text { germline BRCA mutated solid tumors } \\
\text { and triple-negative breast cancer }\end{array}$ \\
\hline CEP-9722 37 & $\begin{array}{l}\text { Teva Pharmaceutical } \\
\text { Industries }\end{array}$ & 2 & Solid tumors \\
\hline \multirow[t]{2}{*}{ BSI-201 39} & \multirow[t]{2}{*}{ BiPar/Sanofi-Aventis } & 1 & Solid tumors \\
\hline & & 2 & Triple-negative breast cancers \\
\hline INO- $1001^{40}$ & Inotek/Genentech & 1 & Melanoma, glioblastoma multiform \\
\hline
\end{tabular}

Table 2. Toxicity profile of PARP inhibitors currently in clinical trials

\begin{tabular}{|c|c|c|}
\hline Drug & Toxicity related to breast cancer & Toxicity related to ovarian cancer \\
\hline Olaparib & $\begin{array}{l}\text { Nausea, vomiting, fatigue, anorexia, headache, } \\
\text { diarrhea }\end{array}$ & GI symptoms, fatigue, anemia ${ }^{44,45}$ \\
\hline Veliparib & Dizziness, nausea, dysgeusia ${ }^{35}$ & Nausea, fatigue, lymphopenia ${ }^{46}$ \\
\hline Talazoparib & $\begin{array}{l}\text { Fatigue, nausea, alopecia, anemia, neutropenia, } \\
\text { thrombocytopenia } 47\end{array}$ & $\begin{array}{l}\text { Fatigue, alopecia, GI symptoms, } \\
\text { anemia, neutropenia, } \\
\text { thrombocytopenia }^{48}\end{array}$ \\
\hline Niraparib & $\begin{array}{l}\text { Anemia, nausea, thrombocytopenia, vomiting, } \\
\text { insomnia, constipation, fatigue, anorexia } 49\end{array}$ & $\begin{array}{l}\text { Anemia, thrombocytopenia, } \\
\text { neutropenia, GI symptoms, fatigue } 49\end{array}$ \\
\hline Rucaparib & $\begin{array}{l}\text { Fatigue, nausea, diarrhea, vomiting, dizziness, } \\
\text { anorexia }^{50}\end{array}$ & GI symptoms, fatigue, anaemia ${ }^{50}$ \\
\hline
\end{tabular}

2008;2008:754190.

3. Espinoza LA, Smulson ME, Chen Z. Prolonged poly(ADP-ribose) polymerase-1 activity regulates JP-8-induced sustained cytokine expression in alveolar macrophages. Free Radic Biol Med 2007;42(9):1430-40.
4. Zerfaoui M, Suzuki Y, Naura AS, et al. Nuclear translocation of $\mathrm{p} 65 \mathrm{NF}-\kappa \mathrm{B}$ is sufficient for VCAM1, but not ICAM-1, expression in TNF-stimulated smooth muscle cells: Differential requirement for PARP-1 expression and interaction. Cell Signal 2008;20(1):186-94. 
5. Farmer H, McCabe N, Lord CJ, et al. Targeting the DNA repair defect in BRCA mutant cells as a therapeutic strategy. Nature 2005;434(7035):917-21.

6. Patel A, Kaufmann SH. Development of PARP inhibitors: an unfinished story. Oncology 2010;24(1):66-68.

7. Mendes-Pereira AM, Martin SA, Brough R, et al. Synthetic lethal targeting of PTEN mutant cells with PARP inhibitors. EMBO Mol Med 2009;1(6-7):315-22.

8. Graziani G, Szabó C. Clinical perspectives of PARP inhibitors. Pharmacol Res 2005;52(1):109-18.

9. Ame JC, Spenlehauer C, de Murcia G. The PARP superfamily. Bioessays 2004;26(8):882-93.

10. Otto H, Reche PA, Bazan F, et al. In silico characterization of the family of PARP-like poly(ADPribosyl) transferases (pARTs). BMC Genomics 2005;6(1):139.

11. Isabelle M, Moreel X, Gagné J-P, et al. Investigation of PARP-1, PARP-2, and PARG interactomes by affinity-purification mass spectrometry. Proteome Sci 2010;8(1):22.

12. Hoeijmakers JH. Genome maintenance mechanisms for preventing cancer. Nature 2001;411(6835):366-74.

13. Lindahl $\mathrm{T}$. Instability and decay of the primary structure of DNA. Nature 1993;362(6422):709-15.

14. Chambon P, Weill J, Mandel P. Nicotinamide mononucleotide activation of a new DNA-dependent polyadenylic acid synthesizing nuclear enzyme. Biochem Biophys Res Commun 1963;11(1):39-43.

15.El Khamisy SF, Masutani M, Suzuki H, et al. A requirement for PARP 1 for the assembly or stability of XRCC1 nuclear foci at sites of oxidative DNA damage. Nucleic Acids Res 2003;31(19):5526-33.

16. D'Amours D, Desnoyers S, D'Silva I, et al. Poly(ADP-ribosyl)ation reactions in the regulation of nuclear functions. Biochem J 1999;342(2):249-68.

17. Lindahl T, Satoh MS, Poirier GG, et al. Posttranslational modification of poly (ADP-ribose) polymerase induced by DNA strand breaks. Trends in biochemical sciences 1995;20(10):405-11.

18. Flohr C, Bürkle A, Radicella JP, et al. Poly(ADP ribosyl)ation accelerates DNA repair in a pathway dependent on Cockayne syndrome B protein. Nucleic Acids Res 2003;31(18):5332-7.

19. Tong W, Yang Y, Cao W, et al. Poly(ADP-ribose) polymerase-1 plays a role in suppressing mammary tumourigenesis in mice. Oncogene 2007;26(26):3857-67.

20. Conde C, Mark M, Oliver FJ, et al. Loss of poly(ADP ribose) polymerase 1 causes increased tumour latency in p53 deficient mice. EMBO J 2001;20(13):3535-43.

21. Molinete M, Vermeulen W, Bürkle A, et al. Overproduction of the poly(ADP-ribose) polymerase
DNA-binding domain blocks alkylation-induced DNA repair synthesis in mammalian cells. EMBO J 1993;12(5):2109.

22. Yang Y-G, Cortes U, Patnaik S, et al. Ablation of PARP-1 does not interfere with the repair of DNA double-strand breaks, but compromises the reactivation of stalled replication forks. Oncogene 2004;23(21):3872-82.

23. Schultz N, Lopez E, Saleh Gohari N, et al. Poly(ADP ribose) polymerase (PARP 1) has a controlling role in homologous recombination. Nucleic Acids Res 2003;31(17):4959-64.

24. Lord CJ, Ashworth A. Targeted therapy for cancer using PARP inhibitors. Curr Opin Pharmacol 2008;8(4):363-9.

25. de Murcia JM, Ricoul M, Tartier L, et al. Functional interaction between PARP 1 and PARP 2 in chromosome stability and embryonic development in mouse. EMBO J 2003;22(9):2255-63.

26. RufA, De Murcia JM, De Murcia G, et al. Structure of the catalytic fragment of poly(AD-ribose) polymerase from chicken. Proceedings of the National Academy of Sciences 1996;93(15):7481-5.

27. Suto M, Turner W, Arundel-Suto C, et al. Dihydroisoquinolinones: the design and synthesis of a new series of potent inhibitors of poly(ADP-ribose) polymerase. Anticancer Drug Des 1991;6(2):107-17.

28. Griffin RJ, Srinivasan S, Bowman K, et al. Resistance-modifying agents. 5. Synthesis and biological properties of quinazolinone inhibitors of the DNA repair enzyme poly(ADP-ribose) polymerase (PARP). J Med Chem 1998;41(26):5247-56.

29.Penning TD, Zhu G-D, Gandhi VB, et al. Discovery and SAR of 2-(1-propylpiperidin-4-yl)-1Hbenzimidazole-4-carboxamide: a potent inhibitor of poly(ADP-ribose) polymerase (PARP) for the treatment of cancer. Bioorg Med Chem 2008;16(14):6965-75.

30.Zhu G-D, Gandhi VB, Gong J, et al. Synthesis and SAR of novel, potent and orally bioavailable benzimidazole inhibitors of poly(ADP-ribose) polymerase (PARP) with a quaternary methylene-amino substituent. Bioorg Med Chem Lett 2008;18(14):3955-8.

31. Scarpelli R, Boueres JK, Cerretani M, et al. Synthesis and biological evaluation of substituted 2-phenyl-2H-indazole-7-carboxamides as potent poly(ADP-ribose) polymerase (PARP) inhibitors. Bioorg Med Chem Lett. 2010;20(2):488-92.

32.Zhu Q, Wang X, Chu Z, et al. Design, synthesis and biological evaluation of novel imidazo [4, 5-c] pyridinecarboxamide derivatives as PARP-1 inhibitors. Bioorg Med Chem Lett 2013;23(7):1993-6.

33. Abdullah I, Chee CF, Lee Y-K, et al. Benzimid- 
azole derivatives as potential dual inhibitors for PARP-1 and DHODH. Bioorg Med Chem 2015;23(15):4669-80.

34. Tutt A, Robson M, Garber J, et al. Phase II trial of the oral PARP inhibitor olaparib in BRCA-deficient advanced breast cancer. ASCO Annual Meeting Proceedings; 2009.

35. Kummar S, Kinders R, Gutierrez ME, et al. Phase 0 clinical trial of the poly(ADP-ribose) polymerase inhibitor ABT-888 in patients with advanced malignancies. J Clin Oncol 2009;27(16):2705-11.

36. Jones P, Altamura S, Boueres J, et al. Discovery of 2-\{4-[(3 S)-Piperidin-3-yl] phenyl $\}-2 \mathrm{H}$-indazole7-carboxamide (MK-4827): a novel oral poly(ADPribose) polymerase (PARP) inhibitor efficacious in BRCA-1 and-2 mutant tumors. J Med Chem 2009;52(22):7170-85.

37.Penning TD. Small-molecule PARP modulators-current status and future therapeutic potential. Curr Opin Drug Discov Devel 2010;13(5):577-86.

38. Plummer R, Jones C, Middleton M, et al. Phase I study of the poly(ADP-ribose) polymerase inhibitor, AG014699, in combination with temozolomide in patients with advanced solid tumors. Clin Cancer Res 2008;14(23):7917-23.

39. Mahany Jr J, Lewis N, Heath E, et al. A phase IB study evaluating BSI-201 in combination with chemotherapy in subjects with advanced solid tumors. ASCO Annual Meeting Proceedings; 2008.

40. Bedikian AY, Papadopoulos NE, Kim KB, et al. A phase IB trial of intravenous INO-1001 plus oral temozolomide in subjects with unresectable stage-III or IV melanoma. Cancer Invest 2009;27(7):756-63.

41.Fong PC, Boss DS, Yap TA, et al. Inhibition of poly(ADP-ribose) polymerase in tumors from BRCA mutation carriers. N Engl J Med 2009;361(2):123-34.

42. Tutt A, Robson M, Garber JE, et al. Oral poly(ADPribose) polymerase inhibitor olaparib in patients with BRCA1 or BRCA2 mutations and advanced breast cancer: a proof-of-concept trial. Lancet 2010;376(9737):235-44.
43. Kaufman B, Shapira-Frommer R, Schmutzler RK, et al. Olaparib monotherapy in patients with advanced cancer and a germline BRCA1/2 mutation. J Clin Oncol 2015;33(3):244-50.

44.Gelmon KA, Tischkowitz M, Mackay H, et al. Olaparib in patients with recurrent high-grade serous or poorly differentiated ovarian carcinoma or triple-negative breast cancer: a phase 2, multicentre, open-label, non-randomised study. Lancet Oncol 2011;12(9):852-61.

45. Kaye SB, Lubinski J, Matulonis U, et al. Phase II, open-label, randomized, multicenter study comparing the efficacy and safety of olaparib, a poly(ADPribose) polymerase inhibitor, and pegylated liposomal doxorubicin in patients with BRCA1 or BRCA2 mutations and recurrent ovarian cancer. J Clin Oncol 2012;30(4):372-9.

46. Puhalla S, Beumer JH, Pahuja S, et al. Final results of a phase 1 study of single-agent veliparib (V) in patients (pts) with either BRCA1/2-mutated cancer $(\mathrm{BRCA}+)$, platinum-refractory ovarian, or basal-like breast cancer (BRCA-wt). ASCO Annual Meeting Proceedings; 2014.

47. De Bono JS, Mina LA, Gonzalez M, et al. First-inhuman trial of novel oral PARP inhibitor BMN 673 in patients with solid tumors. ASCO Annual Meeting Proceedings; 2013.

48. Wainberg ZA, Rafii S, Ramanathan RK, et al. Safety and antitumor activity of the PARP inhibitor BMN673 in a phase 1 trial recruiting metastatic small-cell lung cancer (SCLC) and germline BRCAmutation carrier cancer patients. ASCO Annual Meeting Proceedings; 2014.

49. Sandhu SK, Schelman WR, Wilding G, et al. The poly(ADP-ribose) polymerase inhibitor niraparib (MK4827) in BRCA mutation carriers and patients with sporadic cancer: a phase 1 dose-escalation trial. Lancet Oncol 2013;14(9):882-92.

50. Kristeleit RS, Burris HA, LoRusso P, et al. Phase 1/2 study of oral rucaparib: Final phase 1 results. ASCO Annual Meeting Proceedings; 2014. 


\title{
Обзор ингибирования ДНК репарации с использованием PARP ингибиторов при раковой терапии
}

\author{
Ашиш П. Шах ${ }^{1}$, Чаган Н Пателㄹ, Дипен К Суреджа' ${ }^{1}$, Киртан П Сангхави ${ }^{1}$ \\ 1 Кафедра фармации, Университет Сумандиип Видияпеетх, Вадодара, Индия \\ ${ }^{2}$ Кафедра фармацевтической химии, Фармацевтический колледж Shree Sarvajanik, Mexсана, Индия
}

\begin{abstract}
Адрес для корреспонденции: Кафедра фармации, Университет Сумандиип Видияпеетх Пипария, Вагходия, Вадодара, 391760,Индия

E mail: shah_ashishpharmacy@ yahoo.co.in

Tel: +919909984159
\end{abstract}

Дата получения: 25 мая 2017 Дата приемки: 24 июня 2017 Дата онлайн публикации: 17 июля 2017

Дата публикации: 30 марта 2018

Ключевые слова: репарация повреждений ДНК, Поли (АДФ-рибоза) полимеразы, PARP (ПАРП) ингибиторы, рак

Образец цитирования:

Shah AP, Patel CN , Sureja DK, Sanghavi KP. A review on DNA repair inhibition by PARP inhibitors in cancer therapy. Folia Med (Plovdiv) 2018;60(1):39-47.

doi: 10.1515/folmed-2017-0067
Процесс репарации ДНК предостерегает клетки от воздействия ДНК разрушающего агента разными способами. Большинство способов терапии против рака вызывают повреждения ДНК, которые приводят к апоптозу. Клетка обладает естественной способностью восстанавливать повреждения, которая приводит к развитию резистентности к лекарственным средствам. Ключевыми ферментами в процессе репарации ДНК являются поли (АДФ-рибоза) (ПАР) и поли (АДФ-рибоза) полимеразы (ПАРП/ РАRР). Опухолевые клетки восстанавливают свой дефектный ген в результате дефектной гомологичной рекомбинации (ГР) при наличии ПАРП фермента. ПАРП ингибиторы подавляют ферментные поли (АДФ рибоза) полимеразы (ПАРП), что в свою очередь приводит к апаптозу опухолевых клеток. Текущие клинические показатели дают основание считать что, что роль ПАРП ингибиторов не ограничивается в рамках BRCA мутаций, а они являются достаточно эффективными при опухолях, связанных с ХР дисфункцией. В связи с этим можно утверждать, что исследование в данной области является исключительно перспективным для будущего лечения рака. Настоящий обзор рассматривает в деталях информацию о роли ПАРП при репарации повреждений ДНК, о роли ПАРП ингибиторов и о химии наличных ПАРП ингибиторов. 